\title{
Biofilm production by coagulase-negative Staphylococcus: a review
}

\section{Produção de biofilme por Staphylococcus coagulase-negativo: uma revisão}

\author{
Thaís Gonçalves Gonçalves ${ }^{1 *}$ (1) (orcid.org/0000-0003-3626-2435) \\ Cláudio Dias Timm ${ }^{1}$ (1) (orcid.org/0000-0003-3920-9066)
}

||||||||||||||||||||||||||||||||||||||||||||||||||||||||||||||||||||||||||||||||||||||||||||||||||||||||||||||||||||||||||||||||||||||||||||||||||||||||||||||||||||||||||||||||||||||||||||||||||||||||||||||||||||||||||||||||||||||||||||

\begin{abstract}
This review aimed to describe the biofilm formation ability of coagulase-negative Staphylococcus, addressing its impact to the food industry. Coagulase-negative Staphylococcus have the ability to produce enterotoxins in food, making it an important line of study, as it constitutes a risk to public health. The biofilm formation by these microorganisms requires physicochemical processes, such as hydrophobic forces, which are essential for the first phase of fixing the biofilm on the surface. In industrial facilities, stainless steel equipment is the most associated with the formation of biofilms, due to the presence grooves and cracks. Many species of coagulasenegative Staphylococcus produce biofilm, but the most studied is $S$. epidermidis, as it is the most frequently isolated from food. Coagulase-negative Staphylococcus form biofilm on different surfaces in the food industry, and can become a source of permanent contamination, that can be present in the final product, intended for human consumption. Among other alternatives to combat the formation of biofilm in industrial food facilities, there is the implementation of Good Manufacturing Practices, which is effective in preventing bacterial adhesion, and therefore, the formation of biofilm. However, further studies are needed in order to quantify the occurrence of coagulase-negative Staphylococcus biofilms in the food industry.
\end{abstract}

KEYWORDS: industrial facilities; contamination; public health.
RESUMO: Esta revisão bibliográfica teve como objetivo descrever a capacidade de formaçáo de biofilme por Staphylococcus coagulase-negativo, relacionando seu impacto na indústria alimentícia. Os Staphylococcus coagulase-negativos possuem a capacidade de produzir enterotoxina nos alimentos, tornando-se uma importante linha de estudo, pois constitui um risco para a saúde pública. A formação do biofilme por esses micro-organismos requer processos físico-químicos, como forças hidrofóbicas, essenciais para a primeira fase de fixação do biofilme na superfície. Nas indústrias, equipamentos de aço inoxidável são os mais associados à formação de biofilmes, em decorrência de possuírem ranhuras e fendas. Muitas espécies de Staphylococcus coagulase-negativo produzem biofilme, porém, o mais estudado é o $S$. epidermidis, por ser o mais frequentemente isolado de alimentos. Os Staphylococcus coagulase-negativos formam biofilme em diferentes superfícies de indústrias alimentícias, podendo se tornar uma fonte de contaminação permanente, contaminando o produto final destinado ao consumo humano. Dentre outras alternativas para combater a formação do biofilme nas plantas alimentícias, a implantação das Boas Práticas de Fabricação é eficaz para prevenir a adesão bacteriana, evitando a formação do biofilme. No entanto, são necessários estudos para quantificar a ocorrência de biofilmes de Staphylococcus coagulase-negativos em indústrias alimentícias.

PALAVRAS-CHAVE: indústrias; contaminação; saúde pública. 


\section{INTRODUCTION}

Bacteria of the Staphylococcus genus belong to the Staphylococcaceae family, are cocci, Gram positive, facultative anaerobic, immobile, non-spore-forming, and can produce the catalase enzyme (PRADO et al., 2015). Based on the ability to produce this enzyme, they are divided into two groups. The enzyme producers are called coagulase-positive Staphylococcus (CPS), while those that do not produce it are called coagulase-negative Staphylococcus (CNS) (OLIVEIRA, 2014).

Food poisoning by Staphylococcus spp. is considered the second most commonly reported foodborne illness (BRASIL, 2016), being a common cause of intoxication due to the ingestion of food contaminated with staphylococcal enterotoxins (SES) produced during bacterial multiplication (FERREIRA et al., 2018). According to WONG; BERGDOLL (2002), the amount of enterotoxin needed to cause poisoning is less than $1 \mu \mathrm{g}$. Staphylococcal enterotoxins are heat-resistant proteins that exhibit superantigen action and are able to remain in the food after heat treatment (BASSO, 2013). Although coagulase-negative Staphylococcus species produce lower amounts of SES, they have been reported as agents involved in outbreaks of food poisoning (MOTA et al., 2012).

One of the main virulence factors of Staphylococcus is the ability to form biofilm (LEITE, 2013). The microbial biofilm is a community of cells embedded within a matrix of exopolysaccharides, fixed on a biological or non-biological surface (ANTUNES et al., 2011; DICICCO et al., 2012). The constituted biofilms represent a source of permanent contamination in the industry, since they can become strongly adhered to the surfaces of equipment and facilities, and can contaminate food by releasing parts of them (JOSEPH et al., 2001).

Microorganisms in biofilm become more resistant than in a planktonic state, and can endure thermal stress, mechanical forces, and sanitation processes (CHAVANT et al., 2007). Biofilm also offers protection against $\mathrm{pH}$ changes, osmotic shocks, desiccation, and UV radiation, representing an original source of food contamination in industrial facilities, which can cause economic losses and the spread of food poisoning (CHAVANT et al., 2007). This review aims to make a bibliographic survey on the biofilm formation ability of CNS.

The Staphylococcus genus is divided into 40 species, which are distributed in coagulase-positive or coagulase-negative Staphylococcus, depending on whether or not the coagulase enzyme is synthesized. Most of these are in the CNS group, standing out as representatives S. epidermidis, S. haemolyticus, and S. saprophyticus (BANNERMAN, 2007; KWOK; CHOW, 2003). In the past, it was believed that only CPS produced enterotoxins, however KÜREKCI (2016) demonstrated that CNS also had this ability. Another study carried out under laboratory conditions showed that staphylococcal enterotoxins can be produced by S. xylosus, S. haemolyticus, S. epidermidis,
S. cohnii, S. warneri, and S. sciuri, all belonging to the CNS group (PEREIRA et al., 2001).

Most species of CNS belong to the commensal microbiota of the skin of humans and animals (RAMOS et al., 2015), which is why contamination of food occurs. Coagulase-negative Staphylococcus are related to mastitis in dairy animals, impairing the quality of milk destined to the industry (MARTIN et al., 2015). RAPINI et al. (2005) detected strains of CNS that produce enterotoxins and the toxin that causes Toxic Shock Syndrome in goat cheese handlers.

However, not all species of CNS are pathogenic. Some have been used in the food industry to assist in the ripening of cheeses and meats (PRAX et al., 2013). They have also been explored as initiators for the fermentation of embedded products (PLACE et al., 2003; LEROY et al., 2010).

The biofilm consists of a monospecies or multispecies cell aggregates embedded in a polymeric matrix, containing extracellular polysaccharides, proteins, glycoproteins, and glycolipids (LAWRENCE et al., 1991; FLEMMING et al., 2007; RICKARD et al., 2003) that form a porous and hydrated structure. This structure adheres strongly to a biotic sediment (DICICCO et al., 2012), such as plant and animal tissues, or abiotic, such as various metals and polymers (BOARI et al., 2009), through organic filaments with a protein or polysaccharide structure, called glycocalyx (KASNOWSKI et al., 2010). This base is embedded in an extracellular polymer matrix capsule (MELO, 2008; BOARI et al., 2009; NEVES, 2012) and, once adhered, the microorganisms pass from the planktonic state to a sessile state, forming colonies that, when detach from the structure, return to the initial state. According to BOARI et al. (2009), monospecies biofilms commonly occur in organic tissues, resulting from infectious processes, whereas multispecies biofilms usually settle on other surfaces, such as those present in industrial food facilities.

The staphylococcal biofilm has in its composition extracellular DNA, polysaccharide compounds, teichoic acid, protein adhesives, minerals, and vitamins (HEILMANN, 2011). The bacteria within the biofilm exhibit an altered phenotype regarding growth rate and gene transcription (GIAOURIS et al., 2014). The biofilm formation impairs the action of physical and chemical agents used in cleaning and sanitizing procedures in industrial facilities (MELO, 2008; KASNOWSKI et al., 2010). It also causes difficulty in removing the biofilm from surfaces, damages on equipment by biocorrosion, and reduction of heat transfer and pressure expenditures in pipes and other equipment (DE OLIVEIRA et al., 2013), besides causing deleterious effects on the quality of the final product. In the processing of meat and dairy products, biofilms are identified as a disorder (CHEN et al., 2007), since they contain more than $90 \%$ of the contaminants present in industrial systems (LUCCHESI, 2006).

According to MORALES et al. (2004), the direct fixation of the biofilm on the surface results from physicochemical 
properties. This connection is driven by hydrophobic or electrostatic interactions and by the action of specific adhesins, such as SSP-1 and SSP-2. The accumulation of material on surfaces forms coatings that collaborate for the development of biofilm, and bacterial cells adhered to this material serve as signals for specific receptors in other bacterial cells to stick (CHRISTENSEN et al., 1994; GELOSIA et al., 2001).

Dipole-dipole interactions, hydrogen bonds, ionic covalent bonds, and hydrophobic forces are physicochemical processes that act especially during the irreversible phase and determine the connection of bacteria with other cells or with surfaces (CHMIELEWSKI; FRANK, 2003; BERK, 2018). One of the first phases for the constitution of the biofilm is the fixation of the bacteria on the surface. A greater relevance is attributed to hydrophobicity than to electrostatic interactions, due to the generation of interaction forces that are important in the fixation of microorganisms (ARAÚJO et al., 2010). Therefore, it is possible to predict whether the adhesion is thermodynamically favorable from the determination of hydrophobicity. Physicochemical properties of the surface material, temperature, $\mathrm{pH}$ (MELO, 2008), expression of virulence factors (FLACH et al., 2005), and hydrophobicity (ARAÚJO et al., 2009) are factors that influence the fixation of the macromolecules. Bacterial hydrophobicity is characterized by the energy of attraction between nonpolar or vaguely polar cells immersed in an aqueous medium. Bacterial multiplication phase, growth medium composition, presence of cellular appendages, and excreted polymeric substances are conditions capable of intervening in cellular hydrophobicity. Likewise, the physicochemical properties of surfaces influence the fixation of bacteria (SIMÕES et al., 2010). The free energy of the interaction between two physical beings immersed in water is what determines the hydrophobicity of surfaces and materials. When surface molecules have greater interaction with each other than with water, these molecules are considered hydrophobic. When the interaction of surface molecules is repulsive, it is classified as hydrophilic (ARAÚJO et al., 2009). According to RODRIGUES et al. (2009), bacterial adhesion increases according to the hydrophobicity of the cell surface, as well as the adhesion surface (DONLAN; COSTERTON, 2002). Therefore, bacteria adhere more easily to hydrophobic surfaces, such as polystyrene, while glass and metal tend to be less suitable for this fixation due to their hydrophilic properties (RODRIGUES et al., 2009).

Various virulence factors related to adhesion determine the level of hydrophobicity of the cell, such as pili and fimbriae, flagella and characteristics of the bacterium's outer membrane, as well as several states of electronegativity controlled by polar functional groups, such as hydroxyls, phosphates, carboxyls, and teichoic acid (VENTURINI, 2017). The decrease in oxygen in the medium predisposes to structural changes in the lipopolysaccharide (LPS) of some bacteria, causing an increase in the hydrophobicity of the cell, a fact that indicates that the bacteria have the ability to modify the hydrophobicity characteristics of the external membrane due to changes in the environment. Thus, the presence of LPS in the membrane tends to make cells more hydrophilic, given that when this molecule is lost, the cell becomes more hydrophobic. According to BOARI et al. (2009), Gram-negative bacteria have a competitive advantage in initial adhesion, colonization, and biofilm formation when compared to Gram-positive bacteria. Microorganisms can vary in hydrophobicity, depending on the culture conditions. The hydrophobicity of Gram-negative bacteria increases when the amount of water in the medium decreases, since its outer membrane has a large amount of lipids and a lower amount peptideoglycan. Hydrophobicity is the thermodynamic property most easily influenced by the amount of water in the medium. Gram-positive bacteria, on the other hand, are less affected by the change in the amount of water in the medium, due to a higher content of peptideoglycan and lower lipid content in their membranes. In addition to hydrophobicity, however, other factors also influence bacterial adhesion.

Bacterial biofilms present in food facilities and equipment can separate, colonize other surfaces, and start the formation of a new biofilm, or they can contaminate foods that come into contact with the surface, becoming a chronic form of contamination (KASNOWSKI et al., 2010). This biofilm growth can cause significant damage to the industry, such as contamination of the final product and biocorrosion and damaging of pipes (KASNOWSKI et al., 2010). According to ANDRADE et al. (2003), around 16\% of foodborne disease outbreaks in Brazil are caused by contaminated utensils and equipment; in France, it was responsible for $59 \%$ of these outbreaks in 2001 (MIDELET; CARPENTIER, 2004). In dairy processing facilities, residues are complex, such as fat, proteins, sugars, and minerals, and therefore it is difficult to remove these compounds, which adhere to surfaces firmly (SILVA, 2006). According to CABEÇA (2006), of the surfaces used in industrial food facilities in handling, storage, or processing equipment, stainless steel is identified as the most important source of bacterial contamination. SCHMIDT et al. (2012) proved that this material has grooves and cracks and these irregularities on the surface allow colonization by microorganisms and biofilm formation.

COS et al. (2010) and TRAN; WEBSTER (2013) verified the main biofilm formation sites, associating them to the occurrence of diseases, and concluded that biofilms can be formed on equipment surfaces, inside pipes and on several surfaces. Besides stainless steel, glass, rubber, polypropylene, and iron are surfaces where biofilms can be formed. STOCCO et al. (2017) demonstrated that biofilms could also form on surfaces of carcasses and fish, causing a challenge in several sectors of fish, poultry, and red meat processing. Water, raw food, dust, equipment, and the hands of operators can be sources of contamination for food or for the colonization of 
bacteria, enabling biofilm formation (MOTA et al., 2012; SIMÓES et al., 2010; SREY et al., 2013).

SHARMA; ANAND (2002) observed multispecies biofilms in components of the pasteurization lines in a dairy facility. Studies have shown that stainless steel surfaces of facilities must be treated with ion implantation techniques, which reduces the fixation of bacteria on the surface (ZHAO et al., 2008).

Staphylococcus bacteria produce adhesins, which belong to the group of surface proteins anchored covalently or anchored in the cell wall. This group also includes adhesins, autolysins, and proteins that cross the membrane. S. aureus is capable of expressing more than 24 surface proteins, making its adhesion easier. According to FOSTER et al. (2014), the CNS express lower amounts of these surface proteins, with $S$. epidermidis manifesting 12 proteins (NEVES, 2012).

In Staphylococcus spp., the formation of biofilm is a dynamic process that occurs in three phases - adhesion, proliferation, and formation - and conclude with maturation and dispersion (O'TOOLE et al., 2000; OTTO 2013; LE et al., 2014). MARSHALL et al. (1971) highlighted that the first phase of the adhesion process is reversible, due to the fixation occurring by Van der Walls forces and electrostatic attractions. In the subsequent phase, through glycocalyx, physical interaction occurs between the cell and the surface (MELO, 2008), becoming irreversible. However, other theories report that biofilm formation occurs in five distinct stages — surface conditioning by adsorption of organic material; transport of cells and nutrients to the adhesion site; reversible bacterial adhesion; cell growth; colonization and irreversible bacterial adhesion and release of cells present in the biofilm margin (MACEDO, 2001; SALUSTIANO, 2007).

The adhesion of bacteria to surfaces is mediated by the formation of the intercellular polysaccharide adhesin (PS/A). Subsequently, proliferation and the development of multi-layers occur (HEILMANN; PETERS, 2006). In Staphylococcus spp., the main molecule responsible for intracellular adhesion is called the intracellular adhesion polysaccharide (IAP), through which the cells bind to each other. According to VASUDEVAN et al. (2003), PS/A and IAP have similar conformation, both with a $\beta$ 1-6 polyglycosamine carbon, but are distinguished by a primary substitution in the amine group. According to ADHIKARI et al. (2007) and SHAW et al. (2007), the production of PS/A is mediated by the products of the chromosomal gene ica, organized in a structure composed by four genes: ica $\mathrm{A}, i c a \mathrm{D}$, ica $\mathrm{B}$, and $i c a \mathrm{C}$, in addition to a regulatory gene transcribed in the opposite direction, called icaR.

The expression of the IAPs present in the cell wall (BALABAN et al., 2007) is also responsibility of the icaADBC operon, which, when activated, encodes four proteins that are essential for the synthesis of IAP. The icaA gene codes for the enzyme $\mathrm{N}$-acetylglycosamyl transferase, using UDP-Nacetylglycosamine as substrate. The icaD gene controls the expression of the capsular polysaccharide (GERKE et al., 1998).
A transmembrane protein is coded by the ica $\mathrm{C}$. This protein is formed with the externalization and elongation of the polylactide and icaB is responsible for the IAP deacetylation (GERKE et al., 1998). Authors report the existence of the icaADBC operon in CNS species other than S. epidermidis, such as $S$. caprae, S. lugdunensis, and S. haemolyticus (MACK et al., 2006).

The maturation phase follows the adhesion and the production of slime - which is an extracellular polysaccharide layer that preserves the adherent surface growth (ALCARÁZ et al., 2003) — occurs, balancing the associations between cells and between the surface and thus, enabling bacterial accumulation, and completing the stage of colonization of the surface. In addition, channels are formed in the biofilm structure to transport water and nutrients to the deeper layers. Molecular techniques such as the amplification of DNA sequences by Polymerase Chain Reaction (PCR) are effective for the identification of ica genes (MARTIN, 2015), which are responsible for coding the synthesis of slime, enabling the detection of virulent slime-producing strains. At the end of the steps, there is the detachment of superficial bacterial cells from the biofilm. BAGGE-RAVN et al. (2003) isolated microorganisms from several fish processing facilities. Staphylococcus spp. were among the genera of bacteria isolated by them, with the majority of these isolates having the capacity to form biofilm.

One of the main virulence factors of CNS is the ability to attach to polymeric surfaces, where biofilms can be formed, especially S. epidermidis, which is the most frequently isolated species (COSTA et al., 2004). MALES et al. (1985) reported the ability of $S$. simulans to form biofilm, while STEPANOVIC et al. (2003) reported this ability in S. sciuri, FOKA et al. (2006) in S. haemolyticus and FREDHEIM et al. (2009), and QU et al. (2010), in S. capitis.

The presence of slime in CNS isolated from human catheters was reported, with S. epidermidis, S. haemolyticus, S. warneri, S. xylosus, S. lugdunensis, S. hominis, S. saprophyticus, S. schleiferi, and S. chromogenes being detected. MACK et al. (2006), FREDHEIM et al. (2009) and ROHDE et al. (2010) identified the icaADBC operon in S. caprae, S. lugdunensis, and $S$. haemolyticus, supporting the fact that biofilm formation can be observed in these species (MALES et al., 1985). The icaADBC operon has not been detected very often in biofilm-forming isolates of $S$. haemoliticus. According to QU et al. (2010), S. capitis is capable of producing biofilm even in the absence of the ica $\mathrm{D}$ gene. In contrast, the genes of the icaADBC operon were detected in a non-biofilm-forming S. warneri isolate (BRADFORD et al., 2006; QU et al., 2010).

A study showed that $72 \%$ (59/72) of S. haemolyticus strains grown in Triptona Soy Broth (TSB) supplemented with glucose formed biofilm and in a medium with $\mathrm{NaCl}$ only $31 \%$ (22/72) (FREDHEIM et al., 2009). In another similar study, testing different biofilm formation conditions by CNS isolated from human blood, there was biofilm formation by S. capitis 
in TSB supplemented with $4 \% \mathrm{NaCl}$ and by $S$. warneri in TSB supplemented with $1 \%$ glucose.

Coagulase-negative Staphylococcus counts performed in pasteurized milk by ATAIDE (2006) presented values of $7.0 \times 10^{2}$ and $1.1 \times 104 \mathrm{UFC} / \mathrm{mL}$. As Staphylococcus spp. are sensitive to the temperatures of pasteurization, the authors concluded that this contamination could be attributed to the release of fragments of biofilm, present on some surface of the pasteurizer, on the outlet pipe of the equipment, or on the surface of the storage tank of pasteurized milk. In 2008, another study was carried out in a milk processing facility in Brazil, isolating 25 CNS from the surfaces of equipment. Four of the isolates were from the receiving tank before cleaning, of which one remained after cleaning the equipment. One isolate from the pasteurizer outlet pipe was obtained, even after it had gone through the sanitization process. From the already packaged milk, an isolate was also obtained. These results can be attributed to the formation of biofilm in the equipment, allowing the release of fragments in the already processed milk (SANTOS et al., 2009).

It is concluded that species of CNS have the capacity to form biofilm on different surfaces of equipment and materials used in industrial facilities, which can be a source of contamination for food and generate losses for the industry and a risk to public health. Still, further studies need to be carried out in order to quantify the occurrence of CNS biofilms in the food industry.

ACKNOWLEDGMENT: Not applicable.

FUNDING: This work did not receive any specific grant from funding agencies in the public, commercial, or not-for-profit sectors.

CONFLICTS OF INTEREST: All authors declare that they have no conflict of interest.

ETHICAL APPROVAL: Not applicable.

AVAILABILITY OF DATA AND MATERIAL: Data sharing not applicable to this article as no datasets were generated or analyzed during the current study.

AUTHORS' CONTRIBUTIONS: All authors had the idea for the article, who performed the literature search and data analysis, and who drafted and/or critically revised the work.

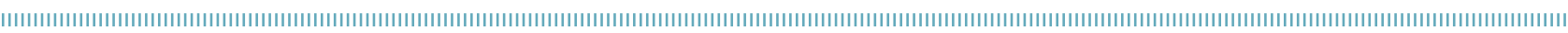

\section{REFERENCES}

ADHIKARI, R.P.; ARVIDSON, S.; NOVICK, R.P. A nonsense mutation in agrA accounts for the defect in agr expression and the avirulence of Staphylococcus aureus 8325-4 traP:kan. Infection and Immunity, v.75, n.9, p.4534-4540, 2007. https://doi. org/10.1128/IAI.00679-07

ALCARÁZ, L.E.; SATORRES, S.E.; LUCERO, R.M.; CENTORBI, O.N.P. Species identification, slime production and oxacillin susceptibility in coagulase-negative staphylococci isolated from nosocomial specimens. Brazilian Journal of Microbiology, São Paulo, v.34, n.1, p.45-51, 2003. https://doi.org/10.1590/S1517-83822003000100010

ANDRADE, N.J.; SILVA, R.M.M.; BRABES, K.C.S. Avaliações das condições microbiológicas em unidades de alimentação e nutrição. Ciência e Agrotecnologia, Minas Gerais, v.27, n.3, p.590-596, 2003. https://doi.org/10.1590/S1413-70542003000300014

ANTUNES, A.L.S.; BONFANTI, J.W.; PEREZ, L.R.R.; PINTO, C.C.F; FREITAS, A.L.P.D.; MACEDO, A.J.; BARTH, A.L. High vancomycin resistance among biofilms produced by Staphylococcus species isolated from central venous catheters. Memórias do Instituto Oswaldo Cruz, Rio de Janeiro, v. 106, n. 1, p.51-55, 2011 . https:// doi.org/10.1590/S0074-02762011000100008
ARAÚJO, E.A.; BERNARDES, P.C.; ANDRADE, N.J.; FERNANDES, P.E.; SÁ, J.P.N. Hidrofobicidade de ribotipos de Bacillus cereus isolados de indústria de laticínios. Alimentos e Nutrição, São Paulo, v.20, n.3, p.491-497, 2009.

ARAÚJO, E.A.; ANDRADE, N.J.; CARVALHO, A.F.; RAMOS, A.M., SILVA; C.A.S.; SILVA, L.H.M. Aspectos coloidais da adesão de micro-organismos. Química Nova, São Paulo, v.33, n.9, p.1940-1948, 2010. https://doi.org/10.1590/ so $100-40422010000900022$

ATAIDE, W. S. Avaliação microbiológica e físico-química ao longo da linha de processamento de leite pasteurizado tipo C. 2006. 68f. Dissertation (Master in Food Science and Technology) Universidade Federal da Paraíba, Paraíba, 2006.

BAGGE-RAVN, D.; NG, Y.; HJELM, M.; CHRISTIANSEN, J. N.; JOHANSEN, C.; GRAM, L. The microbial ecology of processing equipment in different fish industries e analysis of the microflora during processing and following cleaning and disinfection. International Journal of Food Microbiology, Netherlands, v.87, n.3, p.239-250, 2003. https://doi.org/10.1016/ s0168-1605(03)00067-9 
BALABAN, N.; CIRIONI, O.; GIACOMETTI, A.; GHISELLI, R.; BRAUNSTEIN, J.B.; SILVESTRI, C.; MOCCHEGIANI, F.; SABA, V.; SCALISE, G. Treatment of Staphylococcus aureus biofilm infection by the quorum sensing inhibitor RIP. Antimicrobial Agents and Chemotherapy, n.51, p.2226-2229, 2007. https:// doi.org/10.1 128/AAC.01097-06

BANNERMAN, T.L. Staphylococcus, Micrococcus, and other catalasepositive cocci that grow aerobically. In: MURRAY, P. R.; BARON, E. J.; JORGENSEN, J. H.; PFALLER, M. A.; YOLKEN, R. H. Manual of Clinical Microbiology, Washington, v.1, p.390-41 1, 2007.

BASSO, A.P. Resistência a antimicrobianos, genes de enterotoxinas e formação de biofilme em Staphylococcus spp. isolados do Arroio Dilúvio. 2013. 79f. Dissertation (Master in Microbiology Agriculture and the Environment) - Universidade Federal do Rio Grande do Sul, Porto Alegre, 2013.

BERK, Z. Food Process Engineering and Technology. Israel: Academic Press, 2018. 624p.

BOARI, C.A.; ALVES, M.P.; TEBALDI, V.M.R.; SAVIAN, T.V.; PICCOLI, R.H. Formação de biofilme em aço inoxidável por Aeromonas hydrophila e Staphylococcus aureus sob diferentes condições de cultivo. Ciência e Tecnologia de Alimentos, São Paulo, v.29, n.4, p.886-895, 2009. https://doi.org/10.1590/ so101-20612009000400029

BRADFORD, R.; ABDUL MANAN, R.; DALEY, A.J.; PEARCE, C.; RAMALINGAM, A.; D'MELLO, D.; MUELLER, Y.; UAHWATANASAKUL, W.; QU, Y.; GRANDO, D.; GARLAND, S.; DEIGHTON, M. Coagulasenegative staphylococci in very-low-birth-weight infants: inability of genetic markers to distinguish invasive strains from blood culture contaminants. European Journal of Clinical Microbiology $\odot$ Infectious Diseases, Berlin, v.25, n.5, p.283-290, 2006. https:// doi.org/10.1007/s10096-006-0130-2

BRASIL. Ministério da Saúde. Dados Epidemiológicos - DTA período de 2000 a 2015. Unidade Técnica de Doenças de Veiculação Hídrica e Alimentar - UVHA. Coordenação Geral de Doenças Transmissíveis - CGDT. Brasília: Ministério da Saúde, 2016. $11 \mathrm{p}$.

CABEÇA, T.K. Suscetibilidade de microrganismos relacionados com a contaminação de alimentos em biofilme artificial e em suspensão frente a desinfetantes. 2006. 105f. Dissertation (Master in Clinical Analysis) - Faculdade de Farmácia, Universidade Estadual Paulista Júlio de Mesquita Filho, Araraquara, 2006.

CHAVANT, P.; GAILLARD-MARTINIE, B.; TALON, R.; HÉBRAUD, M.; BERNARDI, T. A new device for rapid evaluation of biofilm formation potential by bactéria. Journal of Microbiological Methods, Netherlands, v.68, n.3, p.605-612, 2007. https://doi.org/10.1016/j.mimet.2006.11.010

CHEN, J.; ROSSMAN, M.L.; PAWAR, D.M. Attachment of enterohemorrhagic Escherichia coli to the surface of beef and a culture medium. Food Science and Technology, São Paulo, v.40, n.2, p.249-254, 2007. https://doi.org/10.1016/j.Iwt.2005.10.011

CHMIELEWSKI, R.A.N.; FRANK, J.F. Biofilm formation and control on food processing facilities. Food Science and Food Safety, v.2, n. 1 , p.22-32, 2003. https://doi.org/10.1111/j.1541-4337.2003. tb00012.x
CHRISTENSEN, G.D.; BALDASSARRI, L.; SIMPSON, W.A. Colonization of medical devices by coagulase-negative staphylococci. In: BISNO, A.L.; WALDVOGEL, F.A. Infections associated with indwelling medical devices. $2^{\text {nd }}$ ed. Washington, D.C.: American Society for Microbiology, 1994. p.45-78.

COS, P.; TOTÉ, K.; HOREMANS, T.; MAES, L. Biofilms: an extra hurdle for effective antimicrobial therapy. Current Pharmaceutical Design, v.16, n.20, p.2279-2295, 2010. https://doi. org/10.2174/138161210791792868

COSTA, F.S.; MICELI, M.H.; ANAISSIE, E.J. Mucosa or Skin as source of coagulase-negative staphylococcal bacteremia. Clinical Infectious Diseases, Oxford, v.4, n.5, p.278-286, 2004. https:// doi.org/10.1016/S1473-3099(04)01003-5

DE OLIVEIRA, M.M.; BRUGNERA, D.F.; PICCOLI, R.H. Biofilmes em indústrias de laticínios: Aspectos gerais e uso de óleos essenciais como nova alternativa de controle. Revista do Instituto de Laticínios Cândido Tostes, Minas Gerais, v.68, n.390, p.6573, 2013. https://doi.org/10.5935/2238-6416.20130010

DICICCO, M.; NEETHIRAJAN, S.; SINGH, A.; WEESE, J.S. Efficacy of clarithromycin on biofilm formation of methicillin resistant Staphylococcus pseudintermedius. BMC Veterinary Research, v.8, p.225-231, 2012. https://doi.org/10.1186/1746-6148-8-225

DONLAN, R.M.; COSTERTON, J.M. Biofilms: Survival mechanisms of clinically relevant microorganisms. Clinical Microbiology Review, Washington, v.15, n.2, p.167-193, 2002. https://doi. org/10.1128/cmr.15.2.167-193.2002

FERREIRA, A.A.; MENDONÇA, R.C.S.; DE SOUZA TETTE, P.A.; DE SOUZA SOARES, A.; CARVALHO, M.M. Identificação fenotípica e genotípica de cepas de estafilococos oriundos de uma unidade de abate de aves. Multi-Science Journal, v. 1, n.2, p.50-58, 2018. http://dx.doi.org/10.33837/msj.v1i2.85

FLACH, J.; KARNOPP, C.; CORÇÃO, G. Biofilmes formados em matériaprima em contato com leite: fatores de virulência envolvidos. Acto Scientiae Veterinariae, Porto Alegre, v.33, n.3, p.291-296, 2005.

FLEMMING, H.C.; NEU, T.R.; WOZNIAK, D.J. The EPS Matrix: The house of biofilm cells. Journal of Bacteriology, Washington, v.189, n.22, p.7945-7947, 2007. https://doi.org/10.1 128/JB.00858-07

FOKA, A.; CHINI, V.; PETINAKI, E.; KOLONITSIOU, F.; ANASTASSIOU, E.D.; DIMITRACOPOULOS, G.; SPILIOPOULOU, I. Clonality of slime-producing methicillin-resistant coagulasenegative Staphylococci disseminated in the neonatal intensive care unit of a university hospital. Clinical Microbiology and Infection, v.12, n.12, p.1230-1233, 2006. https://doi. org/10.1111/j.1469-0691.2006.01565.x

FOSTER, T.J.; GEOGHEGAN, J.A.; GANESH, V.K.; HÖÖK, M. Adhesion, invasion and evasion: the many functions of the surface proteins of Staphylococcus aureus. Nature Reviews, v.12, n.1, p.49-62, 2014. https://doi.org/10.1038/nrmicro3161

FREDHEIM, E. G.; KLINGENBERG, C.; ROHDE, H.; FRANKENBERGER, S.; GUSTAD, P.; FLAEGSTAD, T.; SOLLID, J.E. Biofilm formation by Staphylococcus haemolyticus. Journal of Clinical Microbiology, Arlington, v.47, n.4, p.1172-80, 2009. https://doi.org/10.1128/ JCM.01891-08 
GELOSIA, A.; BALDASSARI, L.; DEIGHTON, L.; NGUYEN, T.V. Phenotypic and genotypic markers of Staphylococcus epidermidis virulence. Journal of Clinical Microbiology, v.7, n.4, p. 193-199, 2001. https://doi.org/10.1046/j.1469-0691.2001.00214.x

GERKE, C.; KRAFFT, A.; SÜSSMUTH, R.; SCHWEITZER, O.; GÖTZ, $\mathrm{F}$. Characterization of $\mathrm{N}$-acetylglucosaminyltransferase activity involved in the biosynthesis of the Staphylococcus epidermidis polysaccharide intercellular adhesin. Journal of Biological Chemistry, Mayland, v.273, n.29, p.18586-18593, 1998. https://doi. org/10.1074/jbc.273.29.18586

GIAOURIS, E.; HEIR, E.; HÉBRAUD, M.; CHORIANOPOULOS, N.; LANGSRUD, S.; MORETRO, T.; HABIMANA, O.; DESVAUX, M.; RENIER, S.; NYCHAS, G.J. Attachment and biofilm formation by foodborne bacteria in meat processing environments: Causes, implications, role of bacterial interactions 60 and control by alternative novel methods. Meat Science, v.97, n.3, p.298-309, 2014. https://doi.org/10.1016/j.meatsci.2013.05.023

HEILMANN, C. Adhesion mechanisms of staphylococci. In: LINKE, D.; GOLDMAN, A. Bacterial adhesion. Dordrecht, Netherlands: Springer, 2011. p.105-123.

HEILMANN, C.; PETERS, G. Biology and pathogenicity of $S$. epidermidis. In: VICENT, F.; RICHARD, N.; JOSEPH, F.; PORTNOY, D.; ROOD, J. Gram positive pathogens. Washington, D.C.: ASM Press, 2006. p.560-571.

JOSEPH, B.; OTTA, S.K.; KARUNASAGAR I.; KARUNASAGAR I. Biofilm formation by Salmonella spp. on food contact surfaces and their sensitivity to sanitizers. International Journal of Food Microbiology, Netherlands, v.64, n.3, p.367-72, 2001 . https:// doi.org/10.1016/s0168-1605(00)00466-9

KASNOWSKI, M.C.; MANTILLA, S.P.S; OLIVEIRA, L.A.T.; FRANCO, R.M. Formação de biofilme na indústria de alimentos e métodos de validação de superfícies. Revista Científica Eletrônica de Medicina Veterinária, São Paulo, v.15, p.1-23, 2010.

KWOK, A.Y.C.; CHOW, A.W. Phylogenetic study of Staphylococcus and Micrococcus species based on partial hsp60 gene sequences. International Journal of Systematic and Evolutionary Microbiology, v.53, n. 1, p.87-92, 2003. https://doi.org/10.1099/ijs.0.02210-0

KÜREKCI, C. Prevalence, antimicrobial resistance, and resistant traits of coagulase-negative staphylococci isolated from cheese samples in turkey. Journal of Dairy Science, v.99, n.4, p.26752679, 2016. https://doi.org/10.3168/jds.2015-10725

LAWRENCE, J.R.; KORBER, D.R.; HOYLE, B.D.; COSTERTON, J.W.; CALDWELL, D.E. Optical sectioning of microbial biofilms. The Journal of Bacteriology, v.173, p.6558-6567, 1991. https:// doi.org/10.1128/jb.173.20.6558-6567.1991

LE, K.; DASTGHEY, S.; HO, T.; OTTO, M. Molecular determinants of staphylococcal biofilm dispersal and structuring. Frontiers in Cellular and Infection Microbiology, v.4, p.167, 2014. https:// doi.org/10.3389/fcimb.2014.00167

LEITE, B.A. Estudo da susceptibilidade e resposta dos biofilmes de estafilococos aos agentes antimicrobianos. 2013. $151 \mathrm{f}$. Thesis (Doctor's degree in Biotechnology) - Universidade Federal de São Carlos, São Carlos, 2013.
LEROY, S.; GIAMMARINARO, P.; CHACORNAC, J.P.; LEBERT, I.; TALON, R. Biodiversity of indigenous Staphylococci of naturally fermented dry sausages and manufacturing environments of smallscale processing units. Food Microbiology, v.27, n.2, p.294-301, 2010. https://doi.org/10.1016/j.fm.2009.11.005

LUCCHESI, E.G. Desenvolvimento de sistema de obtenção de biofilmes in vitro e a avaliação de sua susceptibilidade a biocidas. 2006. 77f. Dissertation (Master in Biotechnology) - Faculdade de Engenharia Química, Universidade Estadual de Campinas, Campinas, 2006.

MACEDO, J.A.B. Águas @ águas. São Paulo: Varela, 2001.

MACK, D.; ROHDE, H.; HARRIS, L.G.; DAVIES, A.P.; HORSTKOTTE, M.A.; KNOBLOCH, J.K. Biofilm formation in medical device-related infection. Journal of Artificial Organs, v.29, n.4, p.343-59, 2006. https://doi.org/10.1177/039139880602900404

MALES, B.M.; BARTHOLOMEW, W.R.; AMSTERDAM, D. Staphylococcus simulans septicemia in a patient with chronic osteomyelitis and pyarthrosis. Journal of Clinical Microbiology, v.21, n.2, p.255-257, 1985.

MARSHALL, K.C.; STOUT, R.; MITCHELL, R. Mechanism of initial events in the sorption of marine bacteria to surfaces. Journal General Microbiology, v.68, n.3, p.337-348, 1971. https://doi. org/10.1099/00221287-68-3-337

MARTIN, J.G.P. Biofilmes de Staphylococcus aureus isolados de laticínios produtores de queijo Minas frescal. 2015. Thesis (Doctor's degree in Food Science and Technology) - Universidade de São Paulo, São Paulo, 2015.

MELO, P.C. Estudo fenotípico e genotípico da produção de biofilmes por estirpes de Staphylococcus aureus isoladas dos casos de mastite subclínica bovina. 2008. 103f. Dissertation (Master in Veterinary Medicine) - Universidade Estadual Paulista Júlio de Mesquita Filho, Jaboticabal, São Paulo, 2008.

MIDELET, G.; CARPENTIER, B. Impact of cleaning and disinfection agents on biofilm structure and on microbial transfer to a solid model food. Journal of Applied Microbiology, v.97, n.2, p.262-270, 2004. https://doi.org/10.1111/j.1365-2672.2004.02296.x

MORALES, M.; MENDEZ-ALVAREZ, S.; MARTIN-LOPES, J.V.; MARREIRO, C.; FREYTES, C.O. Biofilm: the microbial bunker for intravascular catheter-related infection. Support Care Cancer, v.12, n.10, p.701-707, 2004. https://doi.org/10.1007/ s00520-004-0630-5

MOTA, R. A.; DE MEDEIROS, E. S.; DOS SANTOS, M. V.; PINHEIRO JÚNIOR, J. W.; MOURA, A. P. B. L.; COUTINHO, L. C. A. Participação dos Staphylococcus spp. na etiologia das mastites em bovinos leiteiros no Estado de Pernambuco. Ciência Animal Brasileira, Goiás, v.13, n.1, p.124-130, 2012.

NEVES, T.C.C.C. Caracterização e avaliação da capacidade produtora de biofilmes em estafilococos coagulase negativos isolados de superfícies do ambiente fabril. 2012, $65 \mathrm{f}$. Dissertation (Master in Food Safety) - Universidade Técnica de Lisboa, Faculdade de Medicina Veterinária, Lisboa, Portugal, 2012. 
OLIVEIRA, A. Biofilme estafilocócico: prevenção, detecção da produção e determinação do perfil de resistência a antimicrobianos. 2014. 143f. Thesis (Doctor's degree in Biology) - Universidade Estadual Paulista Júlio de Mesquita Filho, Botucatu, 2014.

OTTO, M. Staphylococcal infections: Mechanisms of biofilm formation maturation and detachment as critical determinants of pathogenicity. Annual Review of Medicine, v.64, p.175-188, 2013. https://doi.org/10.1 146/annurev-med-042711-140023

O'TOOLE, G.; KAPLAN, H.B.; KOLTER, R. Biofilm formation as microbial development. Annual Reviews in Microbiology, v.54, n. 1, p.49-79, 2000. https://doi.org/10.1 146/annurev.micro.54.1.49

PEREIRA, M.L.; CARMO, L.S.; PEREIRA, J.L. Comportamento de estafilococos coagulase negativos pauciprodutores de enterotoxinas, em alimentos experimentalmente inoculados. Ciência e Tecnologia de Alimentos, São Paulo, v.21, n.2, p.171-175, 2001. https://doi.org/10.1590/SO101-20612001000200009

PLACE, R.B.; HIESTAND, D.; GALLMANN, H.R.; TEUBER, M. Staphylococcus equorum subsp. Linens, subsp. Nov., a starter culture component for surface ripened semi-hard cheeses. Systematic and Applied Microbiology, Netherlands, v.26, n. 1, p.3037, 2003. https://doi.org/10.1078/072320203322337281

PRAX, M.; LEE, C.Y.; BERTRAM, R. An update on the molecular genetics toolbox for staphylococci. Journal of Microbiology, v.159, n.3, p.421-435, 2013. https://doi.org/10.1099/ mic.0.061705-0

PRADO, R.R.; FREITAS, E.A.; VALADARES JÚNIOR, E.C.; COSTA, P.C.; SIQUEIRA, M.C.; ROSSI, D.A. Staphylococcus spp.: importantes riscos à saúde pública. PUBVET, v.9, n.8, p.348-399, 2015. https://doi.org/10.22256/pubvet.v9n8.363-368

QU, Y.; DALEY, A.J.; ISTIVAN, T.S.; GARLAND, S.M.; DEIGHTON, M.A. Antibiotic susceptibility of coagulase-negative staphylococci isolated from very low birth weight babies: comprehensive comparisons of bacteria at different stages of biofilm formation. Annals of Clinical Microbiology and Antimicriobials, v.9, p.16, 2010. https://doi.org/10.1186/1476-0711-9-16

RAMOS, J.L.; DIER-PEREIRA, A.P.; YAMADA-OGATTA, S.F. Determinação do perfil de sensibilidade aos antimicrobianos e formação de biofilme de isolados clínicos de Staphylococcus haemolyticus. In: ENCONTRO ANUAL DE INICIAÇÃO CIENTÍFICA, 29., Anais... Londrina, 2015.

RAPINI, L.S.; CERQUEIRA, M.M.O.P.; CARMO, L.S.; VERAS, J.F.; SOUZA, M.R. Presença de Staphylococcus spp. produtores de enterotoxinas e da toxina da síndrome do choque tóxico em manipuladores de queijo de cabra. Arquivo Brasileiro de Medicina Veterinária e Zootecnia, Minas Gerais, v.57, n.6, p.825-829, 2005. https://doi.org/10.1590/ SO $102-09352005000600019$

RICKARD, A.H.; GILBERT, P.; HIGH, N.J.; KOLENBRANDER, P.E.; HANDLEY, P.S. Bacterial coaggregation: an integral process in the development of multi-species biofilms. Trends in Microbiology, Netherlands, v. 1 1, n.2, p.94-100, 2003. https://doi.org/10.1016/ s0966-842x(02)00034-3
RODRIGUES, B.L.; SANTOS, R.L.; RIZZO, N.N.; TAGLIARI, Z.V.; OLIVEIRA, P.A.; TRENHAGO, G.; RODEGHERI, C.Z.; TAGLIETI, M.R.; DICKEL, L.E.; NASCIMENTO, R.V. Avaliação da hidrofobicidade e da formação de biofilme em poliestireno por Salmonella Heidelberg isoladas de abatedouro avícola. Acta Scientiae Veterinariae, Porto Alegre, v.37, n.3, p.225-230, 2009. https:// doi.org/10.1016/10.22456/1679-9216.16333

ROHDE, H.; FRANKENBERGER, S.; ZAHRINGER, U.; MACK, $D$. Structure, function and contribution of polysaccharide intercelular adhesin (PIA) to Staphylococcus epidermidis biofilm formation and pathogenesis of biomaterial-associated infections. European Journal of Cell Biology, Netherlands, v.89, n.1, p.103-111, 2010. https://doi.org/10.1016/j. ejcb.2009.10.005

SALUSTIANO, V.C. Isolamento, ribotipagem e controle de Bacillus cereus após a pasteurização do leite. 2007. 75f. Thesis (Doctor's degree in Food Science and Technology) - Universidade Federal de Viçosa, Viçosa, 2007.

SANTOS, S.S. Investigação da presença e da formação de biofilmes por estafilococos em micro-usina de beneficiamento de leite. 2009. 57f. Dissertation (Master in Veterinary Medicine) - Universidade Estadual Paulista, São Paulo, 2009.

SCHMIDT, R.H.; ERICKSON, D.J.; SIMS, S.; WOLFF, P. Characteristics of food contact surface materials: Stainless steel. Food Protection Trends, v.32, n.10, p.574-584, 2012.

SHARMA, M.; ANAND, S.K. Biofilms evaluation as an essential component of HACCP for food/dairy processing industry: a case. Food Control, Netherlands, v.13, n.6-7, p.469-477, 2002. https:// doi.org/10.1016/s0956-7135(01)00068-8

SHAW, L.N.; JONSSON, I.M.; SINGH, V.K.; TARKOWSKI, A.; STEWART, G.S. Inactivation of traP has no effect on the agr quorumsensing system or virulence of Staphylococcus aureus. Infection and Immunity, v.75, n.9, p.4519-4527, 2007. https://doi. org/10.1128/IAI.00491-07

SILVA, G.A.V. Avaliação das condições de obtenção do leite e da ação de sanificantes no tanque de expansão em uma propriedade leiteira no município de Candeias/BA. Salvador - BA: estudo de caso. 2006. 102f. Dissertation (Master in Food) - Universidade Federal da Bahia, Salvador, 2006.

SIMÕES, M.; SIMÕES, L.C.; VIEIRA, M.J. A review of current and emergent biofilm control strategies. Food Schi Technology, São Paulo, v.43, p.573-583, 2010. https://doi.org/10.1016/j. Iwt.2009.12.008

SREY, S.; JAHID, I.K.; HA, S.D. Biofilm formation in food industries: A food safety concern. Food Control, Netherlands, v.31, n.2, p.572-585, 2013. https://doi.org/10.1016/j. foodcont.2012.12.001

STEPANOVIC, S.; DAKIC, I.; OPAVSKI, N.; JEZ EK, P.; RANIN, L. Influence of the growth medium composition on biofilm formation by Staphylococcus sciuri. Annals of Microbiology, v.53, n. 1, p.6374, 2003. 
STOCCO, C.W.; ALMEIDA, L.; BARRETO, E.H.; BITTENCOURT, J.M. Microbiological quality control in beef cattle processing. Revista Espacios, v.38, n.22, p.9, 2017.

TRAN, P.A.; WEBSTER, T.J. Understand the wetting properties of nanostructured selenium coatings: the role of nanostructured surface roughness and air-pocket formation. International Journal of Nanomedicine, v.8, n.1, p.2001-2009, 2013. https://doi. org/10.2147/IJN.S42970

VENTURINI, D.D.A. Avaliação da ação de moléculas sinalizadoras produzidas por Pseudomonas aeruginosa na formação do biofilme multiespécie de Escherichia coli e Staphylococcus aureus em superfície de aço inoxidável. 2017. 49f. Undergraduate thesis (Food Technology) - Universidade Tecnológica Federal do Paraná, Curitiba, 2017.
VASUDEVAN, P.; NAIR, M.K. M.; ANNAMALAI, T.; VENKITANARAYANAN, K.S. Phenotypic and Genotypic characterization of bovine mastitis isolates of Staphylococcus aureus for biofilm formation. Veterinary Microbiology, Netherlands, v.92, n.1-2, p.179-185, 2003. https://doi.org/10.1016/ s0378-1135(02)00360-7

WONG, A.C.L.; BERGDOLL, M.S. Staphylococcal food poisoning. In: CLIVER, D.; RIEMANN, H. Foodborne Diseases. Amsterdam: Academic Press, 2002. p.231-248.

ZHAO, Q.; LIU, Y.; WANG, C.; WANG, S.; PENQ, N.; JEYNES, C. Reduction of bacterial adhesion on ion-implanted stainless steel surfaces. Medical Engineering $\odot$ Physics, Netherlands, v.30, n.3 p.341-349, 2008. https://doi.org/10.1016/j. medengphy.2007.04.004 